\title{
Three Factors Affecting Language Learning: Grammar Learning Strategies, Self-efficacy, and Learner Autonomy
}

\author{
İrem Görkem Çetinkaya ${ }^{*}$ Filiz Yalçin Tilfarlioğlu \\ Department of English Language Teaching, Gaziantep University, Gaziantep, Turkey
}

Received March 21, 2020; Revised April 26, 2020; Accepted May 20, 2020

Copyright $(2020$ by authors, all rights reserved. Authors agree that this article remains permanently open access under the terms of the Creative Commons Attribution License 4.0 International License

\begin{abstract}
This study mainly investigated (a) the relationship among grammar learning strategies, self-efficacy and learner autonomy and (b) their effects on academic success. Investigating all of them gives some clues for classroom practice. The study was conducted at Gaziantep University Foreign Languages Higher School with the participation of 350 students from four different proficiency levels (elementary, pre-intermediate, intermediate and upper-intermediate). The data were collected through a questionnaire that has three parts with 65-items. The data collected through the questionnaires were analyzed by means of the quantitative method including calculating descriptive statistics. According to analysis results, there is a positive relationship between grammar learning strategies and academic success $(\mathrm{r}=.185 \mathrm{p}>.01)$, self-efficacy and academic success $(\mathrm{r}=.455 \mathrm{p}>.01)$ and learner autonomy and academic success $(\mathrm{r}=.120 \quad \mathrm{p}>.01)$. When grammar learning strategies, self-efficacy and learner autonomy were investigated together, it was observed that there was a statistically positive relationship with academic success $(\mathrm{r}=.472 \mathrm{p}>.01)$.
\end{abstract}

Keywords Grammar Learning Strategies, Self-efficacy, Learner Autonomy, Academic Success

\section{Introduction}

For students, learning languages is very important for many purposes. The most popular of other languages is English. Although students are eager to learn and speak English and they have many English classes until their university education, most of the students do not use English effectively and they cannot speak English fluently. Learning a language is very important and a necessity for people. In an educational system, learners spend their many years to learn and speak a language. However, at the end of the process, they can't use the language affectively and fluently although they know some rules of the target language. They do not have information on how to manage their learning ways. Learners give different outcomes from each other, because they have individual differences in learning a language. It affects their academic success in a negative way. They have different backgrounds and they need to choose their best way of learning. Even if they have same conditions and same teachers, they do not learn in a same way. There is a great importance in language learning, so it is crucial to investigate how learners learn a language and which factors affect their learning process. There are many factors that affect learners' learning process. It is important for learners to have the factors that affect their learning process in order to dominate their learning in terms of being successful. According to this article, grammar-learning strategies, self-efficacy and learner autonomy are very crucial factors in language learning process. This article aims to explain why the factors mentioned are very important for language learning process.

\subsection{Grammar Learning Strategies}

Learning grammar gives learners to use the language efficiently and correctly. Learners use some techniques when they learn a language. These techniques are called as grammar learning strategies that make learning process more organized and correct (Abri, 2017). Grammar can't be taught separately from language. It is one of the most important factors in language learning process. Even if grammar rules by themselves are not enough to learn and speak a language fluently, they have an important role in 
learning a language. Learners use the language by making mistakes. They find the correct usage at the end of the learning process. However, they need to have much information about the best learning strategy for their own learning process. Grammar rules are important for learners to have a fluent and good communication. Without grammar rules, communication does not happen accurately. Grammar can be considered as the heart of the language (Purpura, 2004). Learners need some rules to present the other skills in English. Grammar has some rules that show how to use the language effectively and correctly. Grammar is a necessity for communicative competence. However, the mother tongue is spoken with lack of grammar rules. Language learners give much importance to grammar. Learning grammar has a crucial role in language learning process. Grammar offers a lot of benefits for language learning (Saaristo, 2015). Grammar learning and teaching cannot be separated from language learning in any time or stage. It is necessary for basic features and characteristics of language. Grammar is one of the best ways to improve communicative competence in language learning (Wang, 2010). With a good knowledge of grammar, learners promote their learning a language in an effective way. In teaching and learning a language, learners need to use drills in especially different aspects from their native language (Paulston, 2014).

There are some difficulties in learning grammar. Some learners and teachers think grammar as just rules and structure. However, teaching grammar is the best chance to improve communicative skills. Even if learners know most of the grammar rules, they experience difficulties in speaking the language. If they use the grammar as a tool in communicative goals, it contributes learners' language learning process especially to speaking skill. Most of teachers try to find ways to make learners more successful. These days, one of the most important things is learners and learning than teachers and teaching (T1lfarlıŏlu \& Yalçın, 2005). So, investigating how learners learn the information is very important. They have individual differences. If learners control their own learning, being successful becomes the result of their efforts (Wenden, 1998). Learning is a very huge area. In this area, learners choose different ways to obtain the information and learn the language. The important thing is that learners are aware of these strategies for them to learn the language. Learning and teaching all the grammar rules is not the first aim in the process of learning language. However, learning cannot happen accurately without grammar rules. In teaching and learning grammar, the first aim should not be to learn the rules and the structure of the target language. The aim should be to speak that language accurately and fluently. Because of that reason, grammar can be learnt unconsciously. Learners learn all grammar rules but it does not mean that learners speak the target language fluently because learning and practicing are indisputably different from each other. The main aim is to raise learners' awareness in language learning strategies.

\subsection{Self-efficacy}

All learners and teachers give importance to learners' achievement in language learning. There are many factors that affect learners' success in language learning process. Some of the learners are more engaged and active in the language classes. However, other learners are not motivated and engaged although they are in the same classroom. There cannot be a strict formula to be successful. However, there are important factors that affect learners' being more engaged in the classroom. There are a number of predictors that affect students learning and motivation. However, it is beyond the aim of this article to explain all of them. This part explains Self-efficacy as a factor that affects learners' achievement. Self-Efficacy is people's beliefs that they are capable of performing a task and duty (Bandura, 1994). In order learners to complete a task successfully, they need to believe their capacity to do the task firstly. If learners have high sense of self-efficacy, they can do the task better and easily. They do not consider the task as a challenge and threat with the sense of self-efficacy. When they have a difficulty in doing a task, they recover their sense of self-efficacy and they spend more efforts and try to do their best to complete the task. When learners overcome the obstacles, they feel more self-efficacious. Easy successes do not contribute to learners' sense of self-efficacy. On the other hand, positive situations raise learners' sense of self-efficacy and they can believe their capabilities more. Self-efficacy beliefs are good factors for performance and motivation (Pajares \& Millers, 1994). Learners strengthen their self-efficacy with performances, experiences and persuasions (Meral \& Colak \& Zereyak, 2012), the infancy process of self-efficacy starts in the family (Bandura, 1994). Self-efficacy of learners improves with learners' achievement and observing others that are in similar situations. Much research shows that self-efficacy has a positive effect on motivation, learning and achievement (Pajares, 1996). If learners have high self-efficacy, they become more successful. However, lack of success does not mean that learners have low self-efficacy because learners who have high self-efficacy give more importance to spending much effort to be successful without giving up until they become successful in completing the task. Efficacy arousal is a process in which learners combine the supports from others and their motivation (Schunk, 1991). Some learners can attribute their successes to their teachers so they do not rely on their capacity to complete a task. When they see the teacher as an only source of information, they do not trust themselves to complete a task (Kissacik, 2016). As a result of this situation, they turn into a teacher-dependent learner. Learner 
engagement is really important for learners' achievement. The more learners are engaged; they become more successful in language learning. Sense of self-efficacy brings successes and high performance in language classes. The other important thing is that learners feel anxiety. Learners' feeling anxiety affects their learning process in a negative way. However, Cubukcu (2008) found that anxiety and self-efficacy levels are uncorrelated. Teachers' sense of self-efficacy is also very crucial in learners' learning process. If a teacher has a high sense of self-efficacy, they can organize the tasks according to learners' level and interests. This situation makes learners' learning more organized and easier. Learners evaluate the task as possible or impossible ones. Teachers' guidance here is extremely important to lead their learners to find their way in language learning process. If they believe themselves, they can do the task and they can success at the end although they doubt their capabilities at the start point.

They need some sources to develop their sense of self-efficacy. Bandura mentioned four sources: mastery experience, vicarious experience, verbal persuasion and physiological states. In mastery experience, is learner create a strong feeling to complete a task, it is easier to success it for them. Repeated successes enhance learners' sense of self-efficacy. On the other hand, repeated failures reduce learners' motivation and engagement in the class. Second source of self-efficacy is vicarious experience. Learners need some feedbacks from other learners. If they find some similarities with others, they feel more confident. The next source of self-efficacy is verbal persuasion. In this source, verbal input is necessary from others. Positive comments make the tasks less challenging for learners in facing with difficulty. The last one is physiological states. Feeling of learners affects their learning in a positive or negative way.

At the beginning of the process of doing a task, learners have questions in their mind. They can evaluate every task as possible and impossible situations about learning a language. In this part, they need their teachers' guidance. Teachers help them to improve their sense of self-efficacy.

\subsection{Learner Autonomy}

The last construct of the article is learner autonomy. It means a capacity to control learners' own learning responsibilities. Learners need desire, ability and freedom to take their own responsibility. These are necessities for learners to be more autonomous. Firstly, the attitude toward learning is really important for success. They should be willing to learn a language. They need to be aware of their goals in language learning process. They are expected to organize their plans and needs. They need to experience the language in real situations. They should have a plan and they need to observe others to have some information about the steps for the tasks. They can reflect what they learn and evaluate their own outcomes and others' outcomes. At the end, they can share their outcomes with others. Learner autonomy means that learners take their own responsibilities in terms of learning. If learners have learner autonomy, they can control their own learning and they feel more autonomous. Feeling good in learners' own actions is very important for achievement. If learners have learner autonomy, they can control their own learning and they feel more autonomous (Nunan, 2003). There has been a great focus on learner autonomy in the classroom and out of the classroom. In learner autonomy, learners need to know their weaknesses and strengths in order to improve the target language. However, today, in classrooms, learners are given just scores. They do not get the detailed reports about their classroom performance.

Developing autonomy is a very long process and is not easy for teachers and learners. Implementing the framework above is a need for a successful learning process with teachers' persistence. It is not impossible to expect from learners to take their own learning responsibility in one day. It is a process in which teachers make efforts by collaborating with learners. Teachers should always encourage learners to reflect their ideas and opinions. Learners always need help from their teachers. Even if they work with peers and groups, they need to feel that their teacher is always in the class and they can get help from teachers. Learners can control their learning on their own. However, teachers guide them until they can monitor and evaluate their learning process correctly and they can regulate themselves. Regulating is a really important part of learning.

\section{Materials and Methods}

The aim of this study is to seek the relationship among grammar learning strategies, self-efficacy, learner autonomy and academic success. With this aim, this chapter is responsible for reporting on the descriptive study in which the statistical techniques are used; procedure of data collection and data analysis and the subjects are studied. First, research design is mentioned, and then research population and sampling, data collecting instruments, validity and reliability of these instruments are presented. In order to make the representation more concrete, a variety of tables and figures representing research population are illustrated in this chapter. 350 volunteers out of 1229 preparatory level students from Gaziantep University Higher School of Foreign Languages participated in this study in 2018-2019 academic years. Students at Gaziantep University the School of Foreign Languages take 24 hours English lessons per week. Main course, reading, writing, listening and speaking are parts of their program. 
Students are in classes according to their level, which is stated with the exams. Self-efficacy, learner autonomy and the use of grammar learning strategies are very crucial variables in academic achievement. There are two aims of this study. The first aim is to find out whether there is a relationship among the use of grammar learning strategies, self-efficacy and learner autonomy. The second aim is to find out what extent the use of grammar learning strategies, self-efficacy and learner autonomy account for academic achievement. With these two aims, data was collected through a questionnaire, which consists of three parts: Self-Efficacy Questionnaire (SEQ), Autonomous Learner Questionnaire (ALQ) and Grammar Learning Strategies (GLS). Cronbach's Alpha was used to determine the reliability. The results show that the reliability of the questionnaire "Grammar Learning Strategies" is .711, the reliability of the questionnaire "Self-Efficacy" is .833 and the reliability of the questionnaire "Learner Autonomy" is .768. The questionnaire used in this study consists of four parts. The first part is about participants' age, gender, duration of studying English and proficiency levels of participants. The second part, third part and last part measured Grammar Learning Strategies, Self-Efficacy and Learner Autonomy respectively. The questionnaire "Grammar Learning Strategies" has 25 items, the questionnaire "Self- Efficacy" has 20 items and the last questionnaire "Learner Autonomy" has 20 items. The questionnaires are scored according to a five-point Likert-type scale. The Likert-type scale ranges from 1 (Never) to 5 (Always). The rearranged forms of the questionnaires were conducted with preparatory class students in Gaziantep University. As in the pilot study, the researcher took necessary permission and informed students about the purpose of the study by visiting classes. Moreover, they were assured that their information kept confidentially, and it was reemphasized that participation wasn't compulsory.

\section{Results}

This article is responsible for reporting the relationship between grammar learning strategies, self-efficacy, learner autonomy and academic success. Success is golden feature for education, teachers and learners. The other aim of this article is to show to what extent the use of grammar learning strategies, self-efficacy and learner autonomy account for academic achievement.

There are some research questions:

\section{Research Question 1}

Is there a relationship between the use of grammar learning strategies and foreign language achievement?
Table 1. Relationship between Grammar Learning Strategies and Academic Success

\begin{tabular}{cccc}
\hline & & $\begin{array}{c}\text { Academic } \\
\text { Success }\end{array}$ & $\begin{array}{c}\text { Grammar Learning } \\
\text { Strategies }\end{array}$ \\
\hline & $\mathrm{r}$ & 1 &, $185^{* *}$ \\
Academic Success & $\mathrm{p}$ & & 0,001 \\
& $\mathrm{n}$ & 300 & 300 \\
Grammar & $\mathrm{r}$ &, $185^{* *}$ & 1 \\
Learning & $\mathrm{p}$ & 0,001 & \\
Strategies & $\mathrm{n}$ & 300 & 300 \\
\hline
\end{tabular}

According to Table 1, there is a positive relationship between grammar learning strategies and academic success $(r=.185 \mathrm{p}>.01)$. This shows that the more learners use grammar learning strategies, the more their academic success increases. There is a positive and meaningful relationship between strategy use and academic achievement in Uslu, Şahin and Ödemiş's study (2016). They investigated the effect of language learning strategies on academic achievement.

\section{Research Question 2}

To what extent does the use of grammar learning strategies predict foreign language achievement?

Table 2. Regression Model Summary of Grammar Learning Strategies and Academic Success

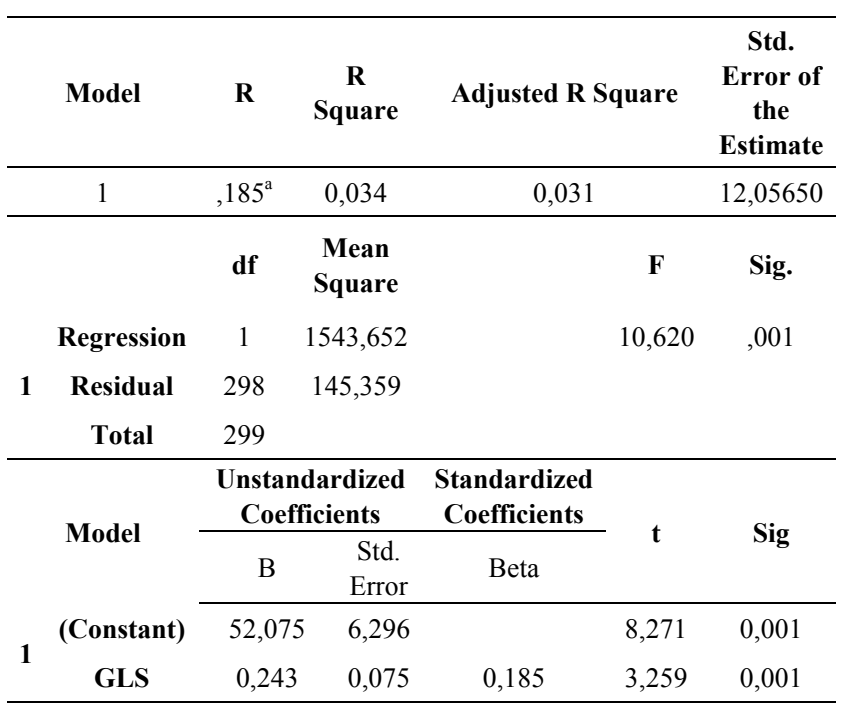

Note: $\mathrm{R}=$ Determination; $\mathrm{R}$ Square $=$ Determination Coefficients; Std. Error $=$ Standard Error of Mean; $\mathrm{df}=$ GLS $=$ Grammar Learning Strategies; SE = Self-Efficacy; LA = Learner Autonomy; $\mathrm{df}=$ Degree of Freedom; Sig. $=\mathrm{p}$ values significant $; \mathrm{F}: \mathrm{F}$ value; $\mathrm{t}=\mathrm{t}$-statistic Student's $\mathrm{t}$ test

Regression analysis was used to find out what extent grammar learning strategies predicts academic success. Grammar learning strategies affect academic success in a positive way as shown in Table 2. Linear regression analysis verifies this relationship, too. However, its affect is not high. According to Table 2, grammar learning strategies account for $3 \%$ of academic success of the participants. 


\section{Research Question 3}

Is there a relationship between self-efficacy and foreign language achievement?

Table 3. Relationship between Self-efficacy and Academic Success

\begin{tabular}{cccc}
\hline & & Academic Success & Self-Efficacy \\
\hline \multirow{2}{*}{ Academic } & $\mathrm{r}$ & 1 &, $455^{* *}$ \\
Success & $\mathrm{p}$ & & 0,000 \\
& $\mathrm{n}$ & 300 & 300 \\
& $\mathrm{r}$ &, $455^{* *}$ & 1 \\
Self-Efficacy & $\mathrm{p}$ & 0,000 & \\
& $\mathrm{n}$ & 300 & 300 \\
\hline
\end{tabular}

According to Table 3, there is a positive relationship between self-efficacy and academic success $(r=.455$ $\mathrm{p}>.01$ ). Like other studies, this study also shows that self-efficacy and academic success are positively related to each other. It means the higher learners have the sense of self-efficacy, the more their success increases. In order to understand to what extent self-efficacy affects academic success, it is necessary to look at the regression model summary of self-efficacy and academic success.

\section{Research Question 4}

To what extent does self-efficacy predict foreign language achievement?

Table 4. Regression model summary of Self-efficacy and Academic Success

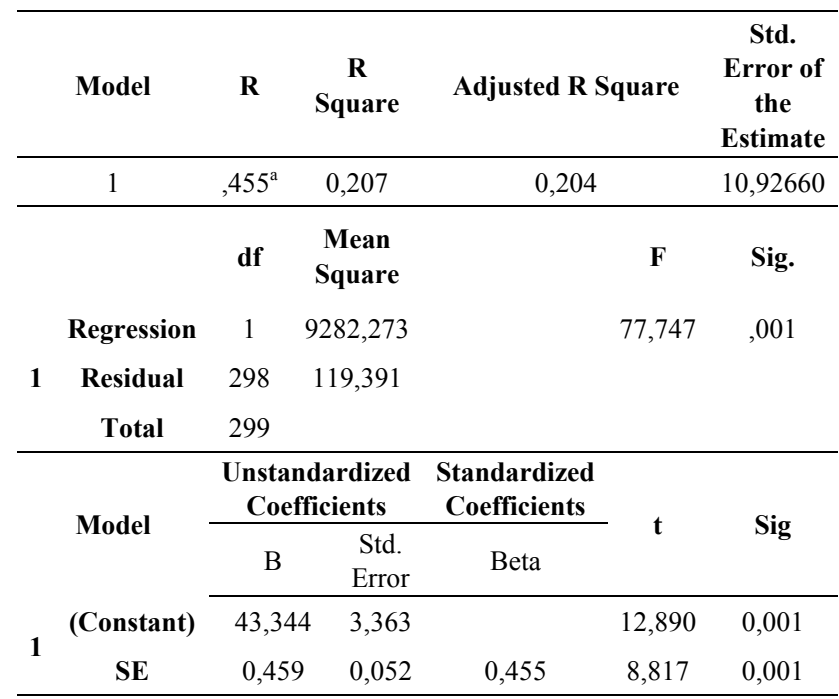

Note: $\mathrm{R}=$ Determination; $\mathrm{R}$ Square $=$ Determination Coefficients; Std Error $=$ Standard Error of Mean; $\mathrm{df}=\mathrm{GLS}=$ Grammar Learning Strategies; SE = Self-Efficacy; LA = Learner Autonomy; $\mathrm{df}=$ Degree of Freedom; Sig. $=\mathrm{p}$ values significant; F: $\mathrm{F}$ value; $\mathrm{t}=\mathrm{t}$-statistic Student's $\mathrm{t}$ test

As shown in table 4, there is a positive relationship between self-efficacy and academic success. In addition, Table 4 verifies the positive relationship by accounting for the $20 \%$ academic success of the participants in this study. To sum up, self-efficacy affects learners' achievement to a significant extent. Learners' self-efficacy beliefs have a positive effect on learners' motivation and achievement (Sadi \& Uyar, 2013). According to their study, self-efficacy can be considered as a big factor in biology course achievement. Meral, Çolak and Zereyak (2012) found a positive relationship between self-efficacy and academic success. According to Lane and Lane (2001), results of their study show that self-efficacy predicts academic success. Köseoğlu (2015) also found a positive relationship between self-efficacy and academic success.

\section{Research Question 5}

Is there a relationship between learner autonomy and foreign language achievement?

Table 5. Relationship between Learner Autonomy and Academic Success

\begin{tabular}{cccc}
\hline & & Academic & Learner Autonomy \\
\hline & $\mathrm{r}$ & 1 &, $120^{*}$ \\
Academic Success & $\mathrm{p}$ & & 0,03 \\
& $\mathrm{n}$ & 300 & 300 \\
& $\mathrm{r}$ &, $120^{*}$ & 1 \\
Learner Autonomy & $\mathrm{p}$ & 0,038 & \\
& $\mathrm{n}$ & 300 & 300 \\
\hline
\end{tabular}

In Table 5, it seems that there is a positive correlation between learner autonomy and academic success $(\mathrm{r}=.120$ $\mathrm{p}$ >.01). The relationship between learner autonomy and academic success is lower than the other factors.

\section{Research Question 6}

To what extent does learner autonomy predict foreign language achievement?

Table 6. Regression Model Summary of Learner Autonomy and Academic Success

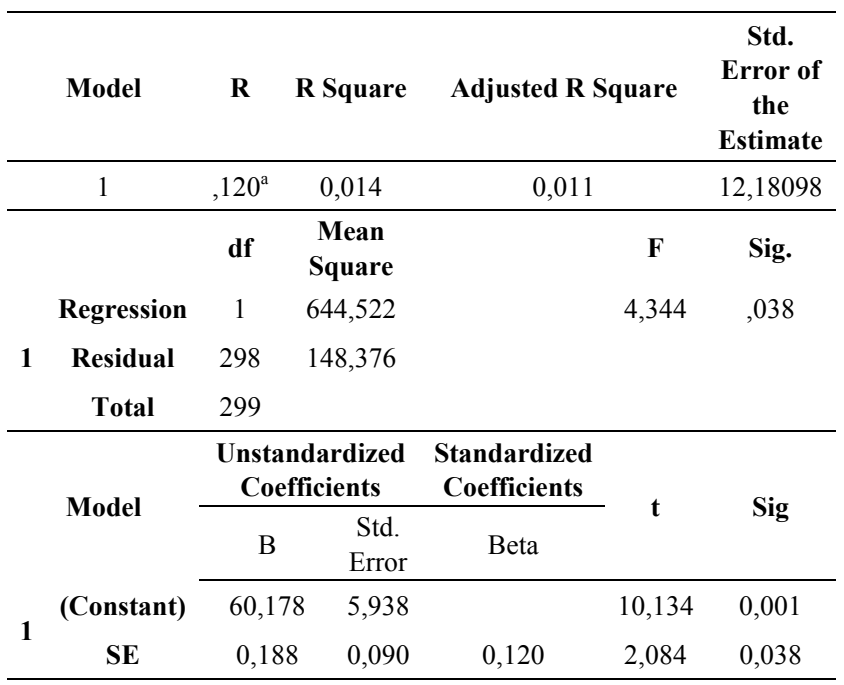

Note: $\mathrm{R}=$ Determination; $\mathrm{R}$ Square $=$ Determination Coefficients; Std. Error $=$ Standard Error of Mean; $\mathrm{df}=\mathrm{GLS}=$ Grammar Learning

Strategies; SE = Self-Efficacy; LA = Learner Autonomy; $\mathrm{df}=$ Degree of Freedom; Sig. $=\mathrm{p}$ values significant; F: $\mathrm{F}$ value; $\mathrm{t}=\mathrm{t}$-statistic Student's $\mathrm{t}$ testSC: Standardized Coefficients

$* \mathrm{p}<0,0$

$* * \mathrm{p}<0,01$

This research question tries to find out to what extent 
learner autonomy predicts academic success. It has low percentage but it accounts for $1 \%$ of academic success.

\section{Research Question 7}

Is there a positive relationship among these three concepts (self-efficacy, learner autonomy and the use of grammar learning strategies?

Table 7. Correlation among Grammar Learning Strategies, Self-Efficacy and Learner Autonomy

\begin{tabular}{ccccc}
\hline & & GLS & SE & LA \\
\hline Academic & $\mathrm{r}$ &, $185^{* *}$ &, $455^{* *}$ &, $120^{*}$ \\
Success & $\mathrm{p}$ & 0,001 & 0,001 & 0,03 \\
& $\mathrm{n}$ & 300 & 300 & 300 \\
Grammar & $\mathrm{r}$ & &, $402^{* *}$ &, $543^{* *}$ \\
Learning & $\mathrm{p}$ & & 0,001 & 0,001 \\
Strategies & $\mathrm{n}$ & & 300 & 300 \\
& $\mathrm{r}$ & & &, $481^{* *}$ \\
Self-Efficacy & $\mathrm{p}$ & & & 0,001 \\
& $\mathrm{n}$ & & & 300 \\
\hline
\end{tabular}

Note: GLS = Grammar Learning Strategies; SE = Self-Efficacy; LA = Learner Autonomy

According to Table 7, there is a positive relationship between grammar learning strategies and self-efficacy $(\mathrm{r}=.402 \mathrm{p}>.01)$, grammar learning strategies and learner autonomy $(\mathrm{r}=.543 \mathrm{p}>.01)$ and self-efficacy and learner autonomy $(\mathrm{r}=.481 \mathrm{p}>.01)$. In the present study, grammar learning strategies, self-efficacy and learner autonomy has an effect on academic success and each other positively.

Table 8. Multiple Regression Model Summary of Grammar Learning Strategies, Self-Efficacy, Learner Autonomy and Academic Success

\begin{tabular}{|c|c|c|c|c|c|c|}
\hline & Model & $\mathbf{R}$ & R Square & \multicolumn{2}{|c|}{ Adjusted R Square } & $\begin{array}{c}\text { Std. } \\
\text { Error of } \\
\text { the }\end{array}$ \\
\hline & 1 & ,472 & 0,223 & 0,215 & & 10,85128 \\
\hline & & df & $\begin{array}{c}\text { Mean } \\
\text { Square }\end{array}$ & & $\mathbf{F}$ & Sig. \\
\hline \multirow{3}{*}{1} & Regression & 3 & 3335,537 & & 28,327 & ,001 \\
\hline & Residual & 296 & 117,750 & & & \\
\hline & Total & 299 & & & & \\
\hline \multirow{6}{*}{1} & \multirow{2}{*}{ Model } & \multicolumn{2}{|c|}{$\begin{array}{l}\text { Unstandardized } \\
\text { Coefficients }\end{array}$} & $\begin{array}{c}\text { Standardized } \\
\text { Coefficients }\end{array}$ & \multirow{2}{*}{ t } & \multirow{2}{*}{ Sig } \\
\hline & & B & $\begin{array}{l}\text { Std. } \\
\text { Error }\end{array}$ & Beta & & \\
\hline & (Constant) & 48,956 & 6,244 & & 7,841 & 0,001 \\
\hline & GLS & 0,092 & 0,081 & 0,071 & 1,134 & 0,258 \\
\hline & SE & 0,508 & 0,060 & 0,504 & 8,466 & 0,001 \\
\hline & LA & $-0,252$ & 0,102 & $-0,161$ & $-2,480$ & 0,014 \\
\hline
\end{tabular}

Note: $\mathrm{R}=$ Determination; R Square $=$ Determination Coefficients; Std. Error $=$ Standard Error of Mean; $\mathrm{df}=\mathrm{GLS}=$ Grammar Learning

Strategies; SE = Self-Efficacy; LA = Learner Autonomy; $\mathrm{df}=$ Degree of Freedom; Sig. $=\mathrm{p}$ values significant; $\mathrm{F}: \mathrm{F}$ value; $\mathrm{t}=\mathrm{t}$-statistic Student's $\mathrm{t}$ test

$* \mathrm{p}<0,05$

$* * \mathrm{p}<0,01$
According to multiple regression model of summary, there is a positive relationship among grammar learning strategy, self-efficacy, learner autonomy and academic success $(r=.472 \mathrm{p}>.01)$. It shows that the constructs of the study are dependent on each other. Moreover, Table 8 accounts for $22 \%$ of academic success. The rest (78\%) of academic success can be related to other factors. This study is the first in the field to investigate the effect of grammar learning strategies, self-efficacy and learner autonomy on academic success. Learners' academic success is affected by many factors. This study investigates three of these factors. The results are shown in findings.

\section{Discussion}

This study carried out to find out the relationship between grammar learning strategies, self-efficacy and learner autonomy toward academic success. Three different questionnaires were adapted to the aim of the present study. One hundred fourteen of the participants are female while one hundred eighty four of participants are male. These participants have different characteristics such as age, gender, duration of studying English and proficiency level. Most of the participants are aged between 17 and $19.49 \%$ of participants have been studying English for 6 months and 38\% of the participants have been studying English for at least four years. Their proficiency levels are elementary, pre-intermediate, intermediate and upper-intermediate.

After conducting the questionnaires, the data was analyzed through SPSS. The reliability of the final form of the questionnaire 'grammar learning strategies, self-efficacy and learner autonomy' are respectively found as $.711, .833$ and .768 which are appropriate for the present study. Demographic variables were analyzed through Independent samples t-test and One-Way Anova. The correlations between variables were accounted by using Pearson Moment Correlation and Regression analysis in SPSS 16.0. According to the results, there is a positive relationship between grammar learning strategies and academic success $(r=.185 \mathrm{p}>.01)$. It does not affect academic success significantly. On the other hand, there is a positive relationship between self-efficacy and academic success $(r=.455 \mathrm{p}>.01)$ and between learner autonomy and academic success $(\mathrm{r}=.120 \mathrm{p}>.01)$. Moreover, there is a positive relationship between grammar learning strategies and self-efficacy $(r=.402$ $\mathrm{p}>.01$ ), grammar learning strategies and learner autonomy $(\mathrm{r}=.543 \mathrm{p}>.01)$ and self-efficacy and learner autonomy $(\mathrm{r}=.481 \mathrm{p}>.01)$. When grammar learning strategies, self-efficacy, learner autonomy and academic success are analysed together, it was found that there was a positive relationship among them $(r=.472 \mathrm{p}>.01)$ Apart from these results, effects of age, gender, durations of studying 
English and proficiency levels investigated on grammar learning strategy, self-efficacy, learner autonomy and academic success. Grammar learning strategies does not seem to be related to the age of participants ( $\operatorname{sig} .=.08>.05)$. In addition, there is of no significant difference between self-efficacy and age (sig. $=.934>.05)$. To sum up, results show that age is not a significant contributor of the constructs of the present study. When looked at the effects of gender, there is a significant difference between gender and academic success $($ sig. $=.001<.05)$, gender and grammar learning strategies $($ sig. $=.0021<.05)$ and between self-efficacy and gender (sig. $=.006<.05$ ). However, there is no significant difference between gender and learner autonomy $($ sig. $=.0384>.05)$. The results indicate that duration of students' studying English has impact on Academic Success, Grammar Learning Strategies, Self-Efficacy (sig. $=.001<0.05, \quad$ sig. $=.036<0.05, \quad$ sig. $=.001<0.05$ respectively). However, it has no effect on Learner Autonomy (sig. $=.164>0.05)$. There is a significant difference between proficiency level and the constructs of the study Academic Success, Grammar Learning Strategies, Self-Efficacy and Learner Autonomy (sig. $=.001<0.05, \quad$ sig. $=.001<0.05, \quad$ sig. $=.001<0.05$, sig. $=.018<0.05$ respectively).

\section{Conclusions}

Grammar learning strategies, self-efficacy and learner autonomy have been debated by many researchers. Researchers have been interested in them. In order to be effective on language learning, it is necessary to investigate the relationship between these factors and their effects on academic success. These factors have been studied separately. However, there is no study to investigate these factors all together on academic success. Therefore, this study aims to find out the relationship between them and their effects on learners' achievement in foreign language education (FLE). The implications of this study may give some clues on how to activate these factors in classroom practice.

\section{Implications and Suggestions for Further Studies}

This study is the first in the field to investigate the relationship among grammar learning strategies, self-efficacy, learner autonomy and academic success. The results show that grammar learning strategies, self-efficacy and learner autonomy are good predictors for academic achievement at foreign language education. This study has implications and suggestions for further studies. Learners' problem is that they do not have information about the factors that affect their academic success. Teachers' task is to search for factors and give information about them to their learners. Being aware of the existence of learning strategies and individual differences are very crucial for them to be successful. Teachers should follow their learners and try to find ways to increase their awareness and make them feel self-efficacious and autonomous learners. Risk-taking is another important issue. Teachers should be aware of the importance of risk-taking for their learners. If learners take risks, they can take their own responsibility. The data of the present study were collected from participants aged 17-25. This study is the first on the field but it has limitations. So the results cannot be generalized to all age groups. In addition, this study was conducted at a state university so; the results of participants from private universities can be studied in the future researches. Teachers should give importance to the construct of the study in order for their learners to improve them. Moreover, further research may be conducted in relation with other factors of language learning such as aptitude, motivation, socio-cultural factors and cognitive style in the process of language learning process. The present study was conducted by using qualitative methods. The other researches can be conducted by using qualitative methods. Future researchers may conduct the study to a wide range of groups in terms of age to investigate it in a different way because the results cannot be generalized to all age groups.

\section{REFERENCES}

[1] R. F. Voss, J. Clarke. Algorithmic Musical Composi.

[2] Abri, A. A. (2017). Grammar Learning Strategies in Omani EFL Classes: Type and Relation to Student Proficiency. Journal of Studies in Education ISSN 2162-6952 2017, Vol. 7, No. 2

[3] Bandura, A. (1994). Self-efficacy. In V. S. Ramachaudran (Ed.), Encyclopedia of human behavior (Vol. 4, pp. 71-81). New York: Academic Press. (Reprinted in H. Friedman [Ed.], Encyclopedia of mental health. San Diego: Academic Press, 1998).

[4] Cubukcu, F. (2008). A Study on the Correlation between Self Efficacy and Foreign Language Learning Anxiety. Journal of Theory and Practice in Education

[5] Kissacik, M. (2016). An Evaluation of English Coursebooks Used in Turkish High Schools for Learner Autonomy: A Descriptive Study.

[6] Köseoğlu, Y. (2015). Self-Efficacy and Academic Achievement - A Case From Turkey

[7] Lane, J., \& Lane, A. M. (2001). Self-efficacy and academic performance. Social Behavior and Personality, 29, 687-694.

[8] Meral, M. \& Çolak, C. \& Zereyak, E. (2012). The 
relationship between self-efficacy and academic performance. Procedia - Social and Behavioral Sciences 46 (2012) $1143-1146$

[9] Nunan, D. (2003). Nine steps to learner autonomy. In Symposium (Vol. 2003, pp. 193-204).

[10] Pajares, M. \& Miller, D. M. (1994). Role of Self-Efficacy and Self-Concept Beliefs in Mathematical Problem Solving: A Path Analysis. Journal of Educational Psychology 1994, V ol. 86, No. 2, 193-203

[11] Pajares, F. (1996). Self-Efficacy Beliefs in Academic Settings. Review of Educational Research Winter 1996, Vol. 66, No. 4, pp. 543-578

[12] Paulston, B. C. (2014). Teachers of English to Speakers of Other Languages, Inc. (TESOL). TESOL Quarterly, Vol. 5, No. 3 (Sep., 1971), pp. 197-208

[13] Purpura, J. E. (2004). Cambridge University Press 978-0-521-80281-9 - Assessing Grammar

[14] Saaristo, P. (2015). Grammar is the heart of language: grammar and its role in language learning among Finnish university students. In J. Jalkanen, E. Jokinen, \& P. Taalas (Eds.), Voices of pedagogical development - Expanding, enhancing and exploring higher education language learning (pp. 279-318). Dublin: Research- publishing.net. doi:10.14705/rpnet.2015.000296

[15] Sadi, Ö. \& Uyar, M. (2013). The Relationship between Self-Efficacy, Self-Regulated Learning Strategies and Achievement: A Path Model. Journal of Baltic Science Education, Vol. 12, No. 1

[16] Schunk, D. H. (1991). Self-efficacy and academic motivation. Educational Psychologist, 26, 207-231.

[17] Tilfarlıoglu, F. Y. \& Yalçın, E. (2005). An Analysis of the Relationship between the Use of Grammar Learning Strategies and Student Achievement at English Preparatory Classes. Journal of Language and Linguistic Studies Vol.1, No.2,

[18] Uslu, M. E. \& Şahin, E. \&Ödemiş, S. İ. (2016). The effect of language learning strategies on academic achievement. Journal of educational and instructional studies. Volume: 6 Issue: 3 Article: 09 ISSN: 2146-7463

[19] Wang, F. (2010). The Necessity of Grammar Teaching. Vol. 3, No. 2; June 2010. ww.w.ccsenet.org/elt

[20] Wenden, A. L. (1998). Metacognitive Knowledge and Language Learning. Applied Linguistics 19/4 515-537. Oxford University Press 1998 